International Journal of

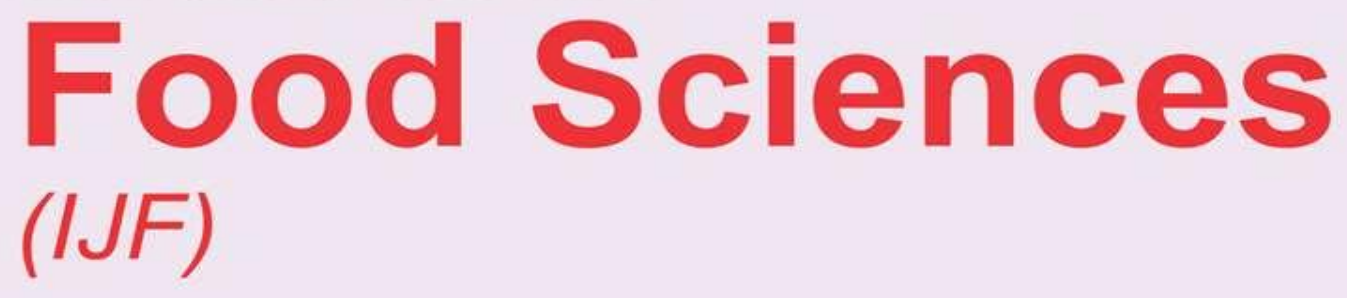

EVALUATION OF BREAKFAST CEREALS PRODUCED FROM FINGER MILLET, WHEAT, SOYBEAN, AND PEANUT BLENDS

Kaida Zubairu Idris, Abba Mansir and Tijjani Ahmad

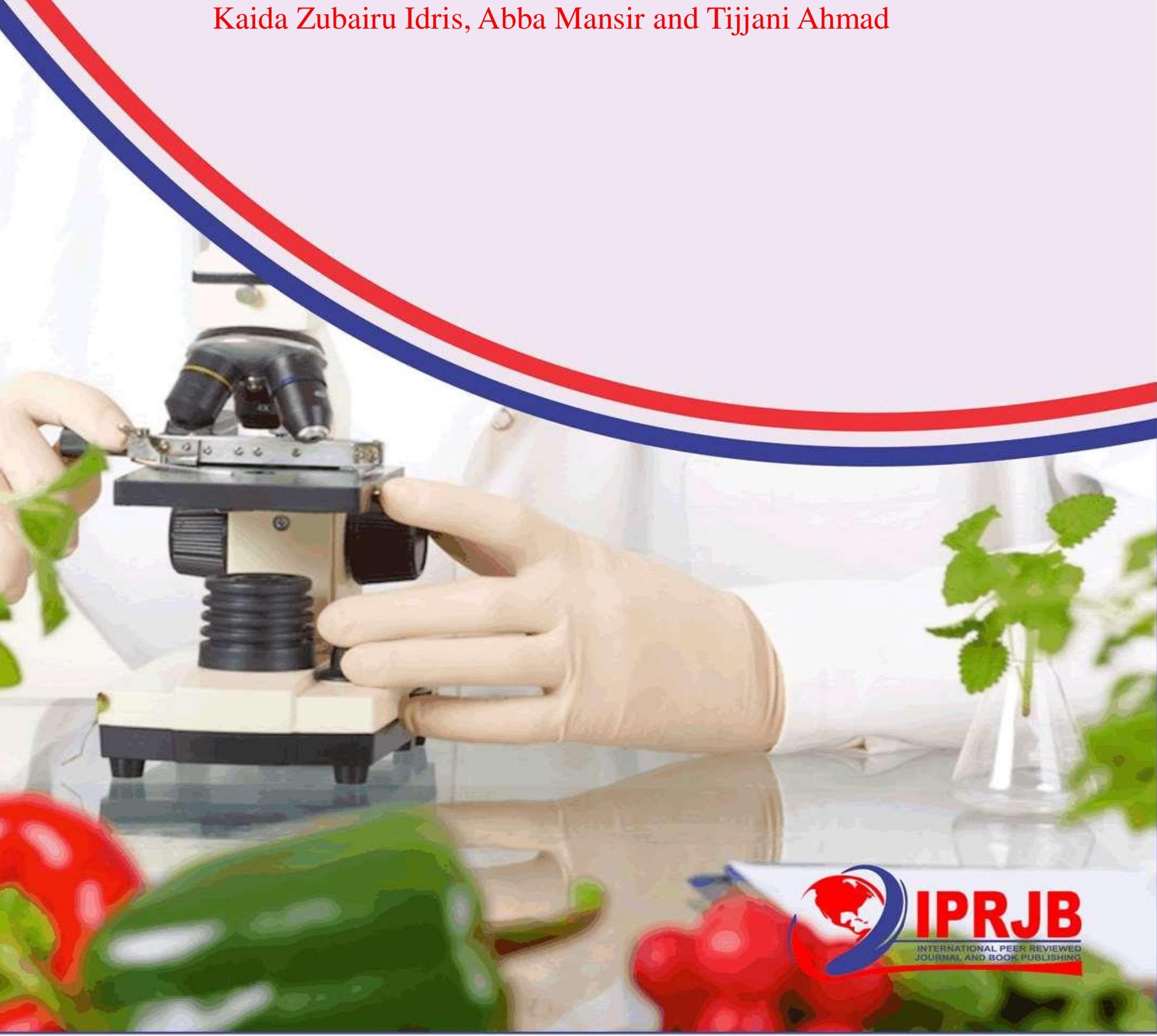




\title{
EVALUATION OF BREAKFAST CEREALS PRODUCED FROM FINGER MILLET, WHEAT, SOYBEAN, AND PEANUT BLENDS
}

\author{
${ }^{1 *}$ Kaida Zubairu Idris \\ ${ }^{1}$ Undergraduate Student: Department of Food Science and Technology, Federal University \\ Dutsinma, Katsina \\ *Corresponding Author's E-mail: idriszubairu09@gmail.com \\ ${ }^{2}$ Abba Mansir \\ Postgraduate Student: Department of Food Science and Technology, Federal University \\ Dutsinma, Katsina \\ ${ }^{3}$ Tijjani Ahmad \\ Undergraduate Student: Department of Food Science and Technology, Federal University \\ Dutsinma, Katsina
}

\begin{abstract}
Purpose: The study sought to evaluate breakfast cereals produced from finger millet, wheat, soybean, and peanut blends

Methodology: In this study, finger millet based breakfast food analysis was conducted, with supplementation of wheat, soybean, and peanut in the ratios of (100:0), (90:10), (80:20), (70:30), and (60:40). These products were analyzed for proximate composition, mineral contents, and sensory attributes using AOAC 2O10, AAS flaming, and method described by Adenguwa et,al., (2014) respectively.

Results: The results for the proximate composition ranged from 61.70 to $71.25 \%, 6.95$ to $7.85 \%$, $2.40 \%$ to $3.20 \%, 9.70 \%$ to $13.5 \%, 1.5 \%$ to $8.50 \%$, and $2.13 \%$ to $4.10 \%$ for carbohydrate, moisture, ash, protein, fat, and fibre respectively. There was significant increase in the protein, fat, fiber, and energy contents, and decrease in only carbohydrate contents at $(p<0.05)$ with increase in supplementation. There were general increase contents of $\mathrm{Zn}, \mathrm{Na}$, and $\mathrm{K}$ with equal decrease in the Ca contents in all the samples $\mathrm{A}-\mathrm{E}$ at $(\mathrm{p}<0.05)$. The mineral composition of this food is good for its efficacy to alleviate some level of macro-minerals deficiencies. The scores for taste ranged between 7.20 - 7.50, the scores range for aroma was from $6.60-6.90$, and $6.23-7.10$ was the score range for mouth feel, the general acceptability which has a score range of $6.67-7.47$ in samples A to E. There was significant difference $(\mathrm{p}<0.05)$ across the samples in all the sensory qualities.
\end{abstract}

Unique contribution to theory, practice and policy: This shows that this breakfast cereal product will be accepted by the consumers when expose to the market due to its characteristic organoleptic sensory appeal. It was recapitulated that this product should be adopted for better nourishment and huger quenching due to lots of condensed nutrients of significant amount.

Keywords: Breakfast, incorporation, cereal, nutrition, evaluation, finger millet, supplementation. 


\subsection{INTRODUCTION}

A Breakfast which is the most important meal of the day is officially well-defined as any form of food material obtained through processes such as rolling, grinding, and swelling or flaking of any cereal crop or in combination with legumes or other plant based crops. Nicklas (2004) reported that breakfast contributes to cognitive performance and improves concentration, supplies one quarter of essential micronutrients to children's diets.

Cereals most of which are ubiquitously grown are highly employed in making breakfast foodstuffs include; corn (maize), wheat, and millet, etc. Cereals are the staple foods of the people providing about $75 \%$ of their total caloric intake and $67 \%$ of their total protein intake (Mckevith, 2004). The common examples of cereal products in Nigeria are; Cornflakes, Pap, kunun dawa, e.t.c. Finger millet (Eleusine coracana), a variety of millet from cereals is good source of nutrients especially minerals and fibre. The Carbohydrate content of finger millet is in the range of 70 $76 \%$. Bhatt et al., (2003) reported that finger millet is about 3-5 times nutritionally superior to the promoted rice and wheat in terms of micronutrients. Finger millet like other cereals is limiting in some essential amino acids such as lysine. Hence, combination of finger millet with legumes like peanut and/or soybean will improve its amino acids profile. Wheat, also a type and most utilized cereal worldwide is a cereal with exceptional quality that makes it a primary ingredient in many food factories. Wheat contains special type of protein called gluten that is responsible for its excellent functional properties. Wheat can ideally serve as the basis for development of functional foods designed to improve the health of millions of consumers (Tomas et al., 2014).

The term legume is derived from the Latin word legume which is in turn believed to come from the verb legere "to gather." Legumes are edible fruits or seeds of pod bearing plants. And the seeds are put to a myriad of uses. (Trevor et al., 2005). The common legumes in Nigeria include cowpea, soybeans, pigeon pea, and peanut. Peanut (Arachis hypogaea), is an oilseed crop cultivated in semi-arid and subtropical regions of the world. Peanut is a major source of edible oil as well as livelihoods for small-scale farmers in the northern Nigeria (Ajeigbe, 2015). Therefore it could be used to improve the nutritional content of foods when added with other components like cereals. Soybean (Glycine max) another legume is one of the world's largest sources of plant protein and oil. Soybean protein has a balanced amino acid profile. Soybeans had been used to enrich other food stuffs such as cassava and cereal products (Ayo et al., 2007). Thus, the aim of this work is to evaluate breakfast cereal produced from finger millet, wheat, soybean and peanut blends.

\subsection{METHODOLOGY}

\subsection{Source of material}

The finger millet, wheat, soybeans, and peanuts were purchased from Wednesday market in Dutsinma, Katsina state. The chemicals and equipment/facilities used were up to standard and were obtained from food processing laboratory of Food Science and Technology Department Federal University, Dutsinma. They crops were subjected to pre-cleaning operations with the aim of producing a safe and wholesome product. 


\subsubsection{Processing of toasted soybean and peanut seeds}

The seeds were cleaned, sorted and cracked using mortar and pestle for easy decortication then toasted in the oven at $70^{\circ} \mathrm{C}$ for 1 hour. The seeds were dried in the sun and dehulled using mortar and pestle to remove the testa. The testa from the dehulled seeds, were separated by winnowing in order to obtain toasted soybean seeds. The seeds were cleaned, sorted and toasted in the oven at $70^{\circ} \mathrm{C}$ for 1 hour. The seeds were dried in the sun and dehulled using hands to remove the testa. The testa from the dehulled seeds, were separated by winnowing in order to obtain toasted peanut seeds.

\subsubsection{Composite formulation and Processing into flour blends}

The finger millet and (wheat, soybean and peanut) grain samples were mixed using material balance at the ratios of 100:0, 90:10, 80:20, 70:30 and 60:40, labeled as A, B, C, D and E. The formulated samples were then weight with electronic chemical balance and milled using harmer mill. Each of the milled four sample obtained were then subjected to sieving process with $1 \mathrm{~mm}$ pore sieve size and packed for analysis.

\subsection{Methods}

\subsubsection{Proximate compositions}

The proximate compositions of the samples were determined using standard methods as described by Association of Official Analytical Chemists (AOAC, 2012). Extraction method was used for the crude fat content determination. Total carbohydrate was determined by difference. Energy calculation was done based on Artwater factor (\% Protein x 4, \% Carbohydrate x 4, \% Fat x 9) $\mathrm{kcal} / 100 \mathrm{~g}$.

\subsubsection{Mineral content analysis}

The mineral content of the products were determined by the AOAC (2012) method using AAS.

\subsection{Preparation of complementary food}

Method described by Olapade et al., (2012) was used. The blends of breakfast cereal flour were thoroughly blended using a warring blender. Each blend $(200 \mathrm{~g})$ was reconstituted with $50 \mathrm{ml}$ water and stirred into smooth slurry followed by addition of boiling water $(200 \mathrm{ml})$ and stirring to obtain consistent paste, which was sweetened sugar.

\subsection{Sensory Analysis}

The sensory evaluation of the formulated breakfast cereal was conducted in the food laboratory of Federal University Dutsinma and performed by method of Iwe (2002). Thirty Semi-trained students were invited as judges. The judges evaluated the breakfast cereals for taste, aroma, mouth feel, appearance, and general acceptability.

\subsection{Statistical Analysis}

The analysis of variance (ANOVA) was used to analyze all data using the statistical package for statistical package for social sciences (SPSS) version 16 for windows. Mean separation was performed by the LSD test $(\mathrm{p} \leq 0.05)$. 


\subsection{FINDINGS AND DISCUSSIONS}

\section{Table 1: Proximate Composition}

\begin{tabular}{lccccccc}
\hline Samples & $\begin{array}{c}\text { Carbohydrate } \\
(\boldsymbol{\%})\end{array}$ & $\begin{array}{c}\text { Moisture } \\
(\boldsymbol{\%})\end{array}$ & $\begin{array}{c}\text { Ash } \\
(\boldsymbol{\%})\end{array}$ & $\begin{array}{c}\text { Fat } \\
(\boldsymbol{\%})\end{array}$ & $\begin{array}{c}\text { Fibre } \\
(\boldsymbol{\%})\end{array}$ & $\begin{array}{c}\text { Protein } \\
(\boldsymbol{\%})\end{array}$ & $\begin{array}{c}\text { Energy } \\
(\boldsymbol{\%})\end{array}$ \\
\hline $\mathbf{A}$ & $71.25^{\mathrm{a}}$ & $6.95^{\mathrm{a}}$ & $2.40^{\mathrm{a}}$ & $1.50^{\mathrm{c}}$ & $8.20^{\mathrm{a}}$ & $9.70^{\mathrm{b}}$ & $337.30^{\mathrm{e}}$ \\
$\mathbf{B}$ & $70.55^{\mathrm{a}}$ & $7.20^{\mathrm{a}}$ & $3.10^{\mathrm{a}}$ & $3.15^{\mathrm{bc}}$ & $6.30^{\mathrm{ab}}$ & $11.20^{\mathrm{ab}}$ & $357.55^{\mathrm{c}}$ \\
$\mathbf{C}$ & $67.95^{\mathrm{ab}}$ & $7.55^{\mathrm{a}}$ & $3.00^{\mathrm{a}}$ & $4.05^{\mathrm{b}}$ & $6.25^{\mathrm{ab}}$ & $11.60^{\mathrm{ab}}$ & $353.05^{\mathrm{d}}$ \\
$\mathbf{D}$ & $64.00^{\mathrm{bc}}$ & $7.70^{\mathrm{a}}$ & $3.20^{\mathrm{a}}$ & $7.20^{\mathrm{a}}$ & $6.10^{\mathrm{c}}$ & $11.75^{\mathrm{ab}}$ & $367.20^{\mathrm{b}}$ \\
$\mathbf{E}$ & $61.70^{\mathrm{c}}$ & $7.85^{\mathrm{a}}$ & $3.10^{\mathrm{a}}$ & $8.50^{\mathrm{a}}$ & $4.25^{\mathrm{c}}$ & $13.15^{\mathrm{a}}$ & $375.90^{\mathrm{a}}$ \\
LSD & 5.98 & 1.04 & 0.85 & 1.83 & 1.99 & 3.40 & 0.00 \\
\hline
\end{tabular}

Values are means of duplicate determinations. Values with the same superscript within the column are not significantly different $(p>0.05)$.

Key; $A=100 \%$ finger millet, $B=90 \%$ finger millet \& $10 \%$ (wheat, soybean, peanut), $C=80 \%$ finger millet \& $20 \%$ (wheat, soybean, peanut), $D=70 \%$ finger millet \& $30 \%$ (wheat, soybean, peanut) $E=60 \%$ finger millet \& $40 \%$ (wheat, soybean, peanut).

\section{Table 2: Mineral composition}

\begin{tabular}{lcccc}
\hline Samples & $\begin{array}{c}\text { Zinc } \\
(\mathbf{m g} / \mathbf{1 0 0 g})\end{array}$ & $\begin{array}{c}\text { Calcium } \\
(\mathbf{m g} / \mathbf{1 0 0 g})\end{array}$ & $\begin{array}{c}\text { Sodium } \\
(\mathbf{m g} / \mathbf{1 0 0 g})\end{array}$ & $\begin{array}{c}\text { Potassium } \\
(\mathbf{m g} / \mathbf{1 0 0 g})\end{array}$ \\
\hline $\mathbf{A}$ & $6.94^{\mathrm{c}}$ & $183.33^{\mathrm{a}}$ & $5.83^{\mathrm{c}}$ & $566.67 \mathrm{c}$ \\
$\mathbf{B}$ & $8.33^{\mathrm{b}}$ & $158.33^{\mathrm{ab}}$ & $8.33^{\mathrm{b}}$ & $1000.00^{\mathrm{b}}$ \\
$\mathbf{C}$ & $8.33^{\mathrm{b}}$ & $116.67^{\mathrm{bc}}$ & $10.83^{\mathrm{a}}$ & $1066.67^{\mathrm{b}}$ \\
$\mathbf{D}$ & $13.89^{\mathrm{ab}}$ & $83.33^{\mathrm{c}}$ & $11.67^{\mathrm{a}}$ & $1166.67^{\mathrm{b}}$ \\
$\mathbf{E}$ & $16.67^{\mathrm{a}}$ & $66.67^{\mathrm{c}}$ & $12.50^{\mathrm{a}}$ & $1400.00^{\mathrm{a}}$ \\
\hline $\mathbf{L S D}$ & 7.31 & 54.75 & 1.79 & 198.50
\end{tabular}

Values are means of duplicate determinations. Values with the same superscript within the column are not significantly different $(p>0.05)$.

Key; $A=100 \%$ finger millet, $B=90 \%$ finger millet $\& 10 \%$ (wheat, soybean, peanut), $C=80 \%$ finger millet \& $20 \%$ (wheat, soybean, peanut), $D=70 \%$ finger millet \& $30 \%$ (wheat, soybean, peanut) $E=60 \%$ finger millet \& 40\% (wheat, soybean, peanut). 
International Journal of Food Sciences

Vol. 1, Issue 1, No. 2, pp 17 - 24, 2019

www.iprjb.org

Table 3: Sensory Attribute

\begin{tabular}{lccccc}
\hline Samples & Taste & Aroma & Mouth feel & Appearance & Gen. Acceptability \\
\hline A & $7.20^{\mathrm{b}}$ & $6.60^{\mathrm{b}}$ & $6.23^{\mathrm{d}}$ & $5.97^{\mathrm{d}}$ & $6.67^{\mathrm{d}}$ \\
B & $7.00^{\mathrm{c}}$ & $6.27^{\mathrm{d}}$ & $6.30^{\mathrm{c}}$ & $6.13^{\mathrm{c}}$ & $6.77^{\mathrm{b}}$ \\
C & $6.87^{\mathrm{d}}$ & $6.40^{\mathrm{c}}$ & $6.03^{\mathrm{e}}$ & $6.57^{\mathrm{b}}$ & $6.63^{\mathrm{e}}$ \\
D & $6.27^{\mathrm{e}}$ & $6.17^{\mathrm{e}}$ & $6.47^{\mathrm{b}}$ & $6.57^{\mathrm{b}}$ & $6.70^{\mathrm{c}}$ \\
E & $7.50^{\mathrm{a}}$ & $6.90^{\mathrm{a}}$ & $7.10^{\mathrm{a}}$ & $7.03^{\mathrm{a}}$ & $7.47^{\mathrm{a}}$ \\
LSD & 0.00 & 0.00 & 0.00 & 0.00 & 0.00 \\
\hline
\end{tabular}

Values are means of duplicate determinations. Values with the same superscript within the column are not significantly different $(p>0.05)$.

Key; $A=100 \%$ finger millet, $B=90 \%$ finger millet \& $10 \%$ (wheat, soybean, peanut), $C=80 \%$ finger millet \& $20 \%$ (wheat, soybean, peanut), $D=70 \%$ finger millet \& $30 \%$ (wheat, soybean, peanut) $E=60 \%$ finger millet \& 40\% (wheat, soybean, peanut).

\subsection{SUMMARY, CONCLUSIONS AND RECOMMENDATIONS}

\subsection{Summary}

\subsubsection{Proximate composition}

The result of the proximate composition of finger millet, wheat, soybeans, and peanuts flour blends of the samples is shown in table 1. where sample A with $100 \%$ finger millet had the highest while sample E had the least carbohydrate content and this was similar to the report of Bhatt et al., (2003) who stated that finger millet have 72 to $79.5 \%$ carbohydrate. The high carbohydrate content contributes more energy value of food formulations.

The mean moisture contents ranged from 6.95 to $7.85 \%$ with sample A having the least while sample E had the highest value followed by D. There was however, no significant difference among all the samples at $\mathrm{P}<0.05$. The result was slightly higher than the findings of Satter et al, (2013) who reported maximum of $3.85 \%$ moisture content of some commercially available weaning foods. Since moisture content is indirectly used as a measure of stability, therefore this food might have relatively short life on shelve.

The ash content increased with supplementation from $2.40 \%$ in sample A to $3.20 \%$ in sample D, where B corresponds with E with $3.10 \%$ ash. However, there was no significant difference among all the samples at $\mathrm{P}<0.05$. The values were within the range obtained by Satter et al, (2013). Although there was no standard associated with quantity of ash in commercial weaning food (FAO/WHO, 1994), the higher ash content indicates a higher mineral content required for proper bone and tooth growth and development.

The fat content of samples A, B, C, D and E were 1.5\%, 3.15\%, 4.05\%, 7.20\%, 8.50\% respectively. 
There was significant differences among the samples at $(\mathrm{p}<0.05)$ except between samples $\mathrm{D}$ and E. The fat content increases from A to $E$ and this could be as a result of the increase in the quantity of oil bearing seeds in the formulation. However, the fat contents obtained are lower than the recommended 10\% FAO (1996), for weaning food formulation.

The fibre content of these samples ranged from $2.13 \%$ in sample $\mathrm{E}$ to $4.10 \%$ fibre content in sample A. however, sample A was significantly different $(\mathrm{P}<0.05)$ from other samples. There was decrease in fibre content as the level of supplementation increases. This is as expected as supplements have relatively low fibre content. The fibre content exceeds the requirement for infants, as it has been documented that the fibre content of infant cereals should not be more than 2.5\% (Odom et al., 2013). But it is still quite important to individuals suffering from gastro intestinal and colon related diseases such as colon cancer and constipation.

There were significant differences $(\mathrm{P}<0.05)$ among the samples for the protein content. And the amount increased with increase in the supplementation from $9.70 \%$ in sample A to $13.5 \%$ in sample E. Similar increase was observed by Kudake et al. (2018). The increase in the protein content could be as a result of the protein contributed by wheat, soybean, and peanut that are protein rich crops. The proportion of protein of this supplemented flour blends can take care of protein malnutrition in population who depends on it as their source of protein.

The energy or calorific value of finger millet supplemented with (wheat, soybeans, and peanut) flour blends as presented in Table 2 shows values ranged from $337.30 \mathrm{kcal} / 100 \mathrm{~g}$ to $375.90 \mathrm{kcal} /$ $100 \mathrm{~g}$ in samples A-E. Sample A (the control), showed least energy values $(\mathrm{p}<0.05)$ while samples E had relatively highest energy. Ejikeme (2005) similarly reported the energy values of up to $411.04 \mathrm{Kcal} / 100 \mathrm{~g}$ for pigeon pea and sorghum flour. The high energy content of this formulated breakfast cereal is advantageous for consumer who is on sedentary lifestyle.

\subsubsection{Mineral Content}

Results show the mineral composition of flour samples A, B, C, D and E in $\mathrm{mg} / 100 \mathrm{~g}$ produced from finger millet and (wheat, soybeans, and peanut) blends in the ratios 100:0, 90:10, 80:20, 70:30, 60:40 respectively. The value of calcium (ranged from $66.67-183.33 \mathrm{mg} / 100 \mathrm{~g}$ ) decreased significantly $(p<0.05)$ across the sample. Singh and Raghuvanshi (2012) reported that the finger millet has the highest calcium content among all cereals $(344 \mathrm{mg} / 100 \mathrm{~g})$, therefore the decrease was probably due to supplementation. Potassium (that occur between $566.67-1400.00 \mathrm{mg} / 100 \mathrm{~g}$ ), zinc (in the range of $6.94-16.67 \mathrm{mg} / 100 \mathrm{~g}$ ), this could be attributed to the appreciable amount $37.2 \mathrm{mg} / 100 \mathrm{~g}$ of zinc found in peanut (Wilkinson, 2005). Zinc plays a vital role in many biological functions such as reproduction. Sodium $(5.83-12.50 \mathrm{mg} / 100 \mathrm{~g}$ range) increased with increase in the level of substitution. Minerals are vital for the overall mental physical well-being and are important constituents of bones, teeth, tissues, and muscles, blood, and nerves cells. They generally help in maintenance of acid base balance, response of nerves to physiological stimulation and blood clotting (Hanif et al., 2006).

\subsubsection{Sensory attributes}

Results for sensory quality attributes of the formulated breakfast cereal blends for taste, aroma, mouth feel, appearance and general acceptability are as presented in Table 6. As for the Taste, Sample E emerged as the one with highest preference with mean value of 7.50 , while the control 
was 7.20 and sample D ranked the least with 6.17 mean values at $(\mathrm{p}<0.05)$. Aroma is a fundamental sensory attribute which refers to the sensations in the nostrils as a result of rising of food or drink volatile compounds. Sample with $40 \%$ supplementation had the highest mean value of 6.90. Sample A had 6.23 while sample D had the least mean score of 6.17. There was however significant difference $(\mathrm{p}<0.05)$ among samples as sample $\mathrm{E}$ was more acceptable. This improvement could probably be due to the flavour impacted by the toasted soybean and peanut.

The mouth feel, which shows the response of sense organs in the mouth, was also ranked. There was significant difference at $\mathrm{p}<0.05$ among samples. The control (100\% finger millet) had a mean value of 6.23 , where samples with $10 \%, 20 \%, 30 \%$, and $40 \%$ wheat, soybean, and peanut blend level of incorporation had $6.30,6.03,6.47$, and 7.10 respectively. The preference test for appearance also carried out. It was generally observed that the inclusion of the supplements improved the appearance of the food. Sample with $40 \%$ (wheat, soybean, peanut) blend had the most acceptable appearance with mean value 7.03. The result was as predicted because the inclusion of soybean and peanut modified the appearance of finger millet as it has been reported by Ranveer. (2010) that finger millet flour has a poor physical appearance. In the General acceptability test, Sample with $40 \%$ (wheat, soybean, and peanut) blend had the highest score for general acceptability with a mean value of 7.47, while the control had the least score of 6.67 . There was however, significant difference $(p<0.05)$ among the samples. The result showed an increasing trend in the level of general acceptability and this could be attributed to the increase in the level of wheat, soybean and peanut in the supplementation.

\subsection{Conclusion}

This study gives the deepest insight on the right processes of developing new breakfast food product from most available nutrient-densed cereal grains in combination with some legumes. The formulated breakfast cereal food as evaluated with significant nutritional value can further be commercialized at industrial level. And can also be administered or recommended to malnourished individuals. These will in turn enhance the developments of a nation like Nigeria.

\section{REFERENCES}

Ajeigbe, H. A., Waliyar, F., Echekwu, C. A., Ayuba, K., Motagi, B. N., Eniayeju, D., \& Inuwa, A. (2014). A Farmer's guide to groundnut production in Nigeria. Patancheru, 502(324), 36.

AOAC (2012), official method of analysis association of analytical chemists. $19^{\text {th }}$ edition, washington DC, 121-130

Ayo, J.A., Ayo, V.A., Nkama, I., Adewori, R. (2007). Physico-chemical, in vitro digestibility and organoleptic evaluation of 'acha' wheat biscuit supplemented with soybean flour. Nigerian Food Journal, 25(1): 77-89.

Bhatt, A., Singh, V., Shrotria, P.K., Baskheti, D.C. (2003). Coarse Grains of Uttaranchal: Ensuring sustainable Food and Nutritional Security. Indian Farmer's Digestion, 34-38.

Desai, A. D., Kulkarni, S. S., Sahu, A. K., Ranveer, R. C., and Dandge, P. B. (2010). "Effect of supplementation of malted nutritional and sensorial quality characteristics of cake" Food Sci. Tech. 2010, 2(1):67 
Ejikeme, Anthonia Nwamaka, (2005). Production and evaluation of breakfast cereal produced from figeon pea (cajanus cajan) and sorghum (sorghum bicolor) blends. (Master's thesis). NSUKKA. Nigeria

FAO of the United Nations (1996) "Grain Legumes in Africa 3rd Edition" Food and Agricultural Organization, Rome, 82-83.

Hanif R., Igbal Z, Igbal M, Honit and Rasged M (2006). Use of vegetables as nutritional food. Role in human health. Journal of Agriculture and Biological Scienece, 1:18-20.

Iwe MO. Hand book of sensory method and analysis. Enugu, Nigeria: Rojoint communications. Services limited; 2002, 14.

Kim, W. (2005). Soybean;Processing Characteristics of Soybean, 260-268, Korea University Press, ISBN 89-7641-562-0

Kudake D.C, et al, (2018).fortification of wheat flour with ragi flour: effect of physical, nutritional, antioxidant, and sensory profile of noodles. Current resources of nutrition and food science, $6(1)$.

McKevith, B. (2004). Nutritional Aspects of Cereals Final Report to the Home Grown Cereal Authority, Nutrition Scientist, British Nutrition Foundation

Mohammed, A. Satter, Syeda Absha Jabin, Nusrat Abedin, Taslima Arzu, Kanika Mitra, Abdullah, A.M., and Paul, D.K.. (2013). Development of nutritionally enriched instant weaning food and its safety aspects African Journal of Food Science, 7(8):238-245

Nicklas, T.A. and OeeNeil, C. (2004). Importance of Breakfast consumption to Nutrition of Children, Adolescents and Young adults. Nutrition Today, 30 (1): 30-39.

Odom, S.L., Wong, C., Hume, K., Cox, A.W., Fetting, A., Kucharczyk, S., Schultz, T.R. (2013). Evidence-based practices for children, youth, and young adults with autism spectral disorder. Chapel Hill: the University of North California, frank porter graham child development institute, autism evidence-based practice review group.

Olapade, A.A., olunwole, O.B., Oluwole and Aworh, O.C. (2012). "Physicochemical properties and consumer acceptability of instance cowpea (Vigna unguiculata) powder for complementary food. African journal of food science and technology, 3(4): 102-106.

Singh, P. and Raghuvanshi, R.S. (2012). Finger millet for food and nutritional security. African Journal of food Science, 6(4):77-84.

Tomas, K., Lacko-Bartošová, M., Kobida, L. (2014). Free Phenol Content and Properties of Refined and Whole Wheat Flour and Bread, Department of Food Science. Antioxidants, 2: 370-383.

Trevor, L.W., Claire, D., Cliff, L.H., Rod, C. and Michael, A. G. (2005). Can we improve the Nutritional Quality of Legume seeds? PakistanJournal of Nutrition, 4 (4): 250 -256.

WHO (1994). Codex Alimentarius Standards for Foods for Special Dietary Uses (including foods for infants and children, Vol. 4. Joint FAO/WHO Food Standards Program Rome: WHO, Codex Alimentarius Commission. 